\title{
Renewable energy generation system connected to micro grid and analysis of energy management: a critical review
}

\author{
Pranita Rathod', Sanjoy Kumar Mishra', Sujit Kumar Bhuyan² \\ ${ }^{1}$ Department of Electrical Engineering, G H Raisoni University, Amravati, India \\ ${ }^{2}$ Resource Assessment and Asset Analysis (RAAA), Manikaran Analytics Limited, Dwarka, India
}

\begin{tabular}{l} 
Article Info \\
\hline Article history: \\
Received May 31, 2021 \\
Revised Jan 17, 2022 \\
Accepted Jan 26, 2022 \\
\hline
\end{tabular}

Keywords:

Energy management Hybrid renewable energy

Lithium batteries

SOFC

Super capacitor

\begin{abstract}
Renewable energy generations have been employed throughout the world in order to meet the increasing load demand. It is a pollution free and abundantly accessible. The generation cost has been reduced because of more research advancement. Photovoltaic (PV) can't generate throughout the day due to weather condition. In order to maintain the continuity of power generation a hybrid renewable generation system (HRGS) concept has been considered in this research work. HRGS is an integration of more than one renewable energy which consists of PV, wind, solid oxide fuel cell (SOFC), an auxiliary unit (AU). AU is used as a backup generation which can generate power when all the renewable energy fails to generate. AU may be of diesel generator (DG) or super capacitor. This paper discusses the various parts of HRGS and its comparison. Furthermore, its impact of energy management so as to deliver the energy to the grid in a continuous and reliable manner. Therefore, a detail study of different component of HRGS \& renewable energy has been highlighted which will be helpful for the new researchers for advancement of power generation and its control strategy of energy management connected to the grid.
\end{abstract}

This is an open access article under the CC BY-SA license.

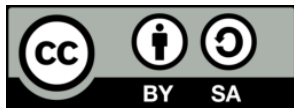

\section{Corresponding Author:}

Sanjoy Kumar Mishra

Department of Electrical Engineering, G H Raisoni University,

Amravati, India-444701

Email: sanjay29y@gmail.com

\section{INTRODUCTION}

In recent years, renewable energy has been the primary source of generation which contribute major parts of generation across the world. The renewable energy generation is attracting more attention due to pollution free activity on the environment. It's used because of economic operation and long-life span but installation cost is more to save electricity cost in the long run. Its generation is supplied through isolation mode and grid connected mode. The merit of renewable energy sources used because it is available abundantly in nature and environmental friendly. The rate of increase in electricity consumption is expected to raise by approximately $40 \%$ to $45 \%$ by 2030 . Renewable energy source captures the attraction for environmental consideration; pollution-free, easy availability, and continuous in nature. Out of other renewable energy sources available in the market, the photovoltaic (PV) cell energy generation is the most promising resources because of its affordable cost, simple implementation, and portability. In order to have the continuous power supply and the efficiency improvement, it is coordinated with other renewable energy sources like wind farm, fuel cell, electrolyze and diesel-generator set to form hybrid renewable energy sources. This is generally combined with a battery storage system. Thus, the implementation of the hybrid renewable energy system is formed where more than two renewable energy sources are implemented. The 
lithium-ion cell is the most important energy storage system used to store the electricity generation on an emergency need. Lithium-ion batteries are one of the most advanced alternate sources for storing power. In the past few decades, it has the most attracting domain for the researchers to utilize in many applications like electric vehicle, electric train and tram. A micro porous polymer membrane is used to separate the electrodes from each other and allows to exchange of Li-ions between the two electrodes. They compare various families of battery materials and analyze the performance, limitations, and problems in commercial battery material development [1]. Mao et al. investigates the limiting electrode in the lithium-ion battery for fast charging and analyze the behavior of cathode and anode in extreme fast charging (XFC) condition. They designed an asymmetric cell of three electrodes to analyze the performance behavior of cathode and anode in the lithium-ion battery in an XFC situation [2]. Lu et al. presents the review on conversion type anode material of lithium-ion battery and their storage structure. They also discussed the problems faced in the implementation of nano-engineering with high-performance conversion-type anode materials including low-dimensional structure, hollow structure, and hybridization with various carbonaceous materials [3], [4]. Shimamura et al. stated the performance of advanced lithium-ion for vehicles and present the various aspects of design, construction, and output power of lithium-ion battery has improved the performance of vehicle [5]. Lithium-ion batteries will also be stored green energy from renewable energy sources like solar and wind [6], [7]. Renewable energy sources such as diesel, photovoltaic (PV), wind and PV/wind are used to generate energy. Such energy systems are called hybrid energy systems. For the most remote areas, hybrid renewable energy sources is considered to be the cheapest and most efficient system for power generation.

This review paper discusses in two sections. The first section describes in detail the features, mechanism, design, construction, and working principles of lithium batteries and its challenges, advantages, disadvantages, and limitations of different types of batteries. The second section introduces hybrid renewable energy systems and reviews various techniques for diagnosing defects. Several emerging technologies for fault detection have developed using different converter topologies for fault clearing. Finally, its material review, and critical review have introduced energy management in hybrid renewable energy systems based on renewable energy sources. Lithium-ion batteries are more powerful batteries than any other family of rechargeable batteries in terms of volume, size, density and capacity. Figure 1 shows the year wise demand of lithium battery. It is observed that the lithium battery sales have been increasing exponentially within two decade (1999-2020) and reaches maximum point of sales in $100 \mathrm{GWh}$. Figure 2 shows the comparative analysis of existing research of lithium-ion battery density and specific energy with respect to other commercial batteries.

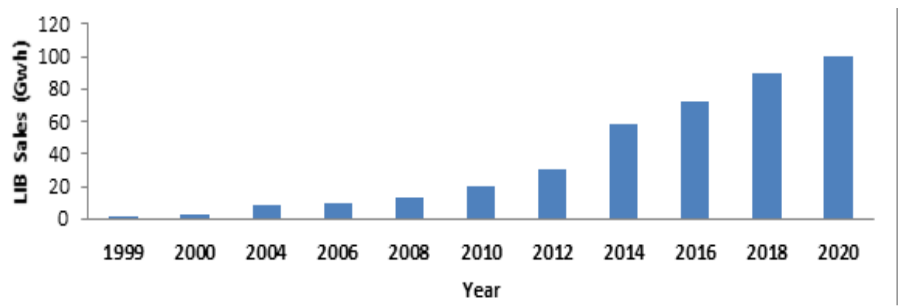

Figure 1. Year wise demand of lithium batteries

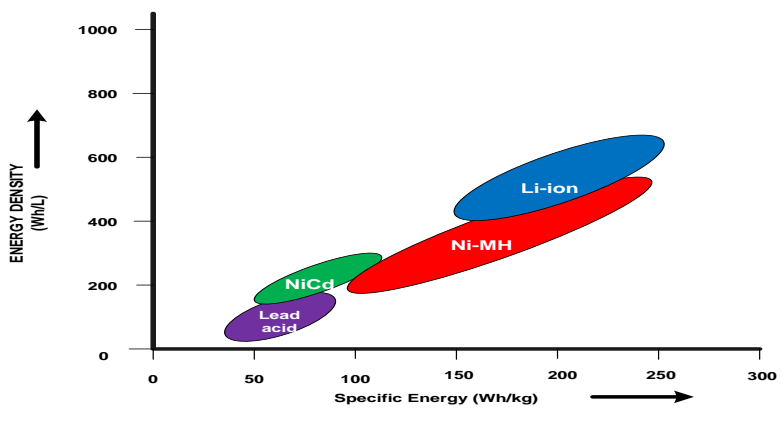

Figure 2. Specific energy and energy density [7]

First, in the 1970s, non-rechargeable lithium batteries were developed. After the 1980's lithium rechargeable batteries were developed based on anode materials. All light materials used in lithium batteries with high electrochemical properties and large specific energy. Lithium batteries are based on cell connection 
in parallel as well as cell or a combination of both. Multiple cells can be combined from a module, and multiple sections can be combined from a battery. Lithium-ion batteries have cathodes and anodes that are connected using electrolytes. Electrode material selection is an important task for the performance of batteries; probably it depends on capacity, cell voltage, and cycling. But they suffer from various issues like volume expansion in the lithiation process [7]-[10], bad electrical contact, and decrease cycling performance. Lithium batteries increase the unwanted reaction (dendrite) between the li and electrode which causes decreases the battery life. Figure 1 shows the year wise demand of Lithium battery. It is observed that the lithium battery sales have been increasing exponentially within two decade (1999-2020) and reaches maximum point of sales in $100 \mathrm{GWh}$. Figure 2 depicts the specific energy and energy density. It shows that the demand of Lithium-ion battery is increasing rapidly due to its performance.

\section{PV SYSTEM}

Over the past few decades, a lot of research has been done on renewable energy generation such as solar energy, wind energy, fuel cell energy, due to environmental and economic implications [11], [12]. A summary of various PV system is discussed in the Table 1 from the referred paper [13]-[18].

Table 1. Summary of various PV system

\begin{tabular}{|c|c|c|c|c|c|c|}
\hline Author & Technique & Micro-grid & Implementation & Operation Mode & Advantages & Contribution \\
\hline [13] & $\begin{array}{l}\text { Reconfigurable } \\
\text { solar converter }\end{array}$ & $\begin{array}{l}\text { Power } \\
\text { plant }\end{array}$ & Hardware & $\begin{array}{l}\text { PV-to-Grid/PV-to- } \\
\text { Battery/PV/Battery- } \\
\text { to-Grid }\end{array}$ & $\begin{array}{l}\text { A single electrical } \\
\text { conversion system was } \\
\text { used to operate in } \\
\text { different operation } \\
\text { modes. The solar plant } \\
\text { is more easily } \\
\text { controlled and due to } \\
\text { the ease of operation } \\
\text { its maximum energy } \\
\text { can be transferred at } \\
\text { low cost. }\end{array}$ & $\begin{array}{l}\text { Additional } \\
\text { alternating current } \\
\text { (AC) inductors have } \\
\text { been added if AC } \\
\text { filter inductance is } \\
\text { not available for } \\
\text { charging. Frame } \\
\text { ratio-integral current } \\
\text { has been proposed } \\
\text { for energy control }\end{array}$ \\
\hline$[14]$ & $\begin{array}{l}\text { Reconfigurable } \\
\text { Solar } \\
\text { Converter/PV } \\
\text { Battery }\end{array}$ & $\begin{array}{l}\text { PV solar } \\
\text { plant }\end{array}$ & MATLAB & $\begin{array}{l}\text { PV-to-Grid/ PV-to- } \\
\text { Batteries/Batteries-to- } \\
\text { Grid/PV-Battery-to- } \\
\text { Grid }\end{array}$ & $\begin{array}{l}\text { Slowly energy } \\
\text { variation is achieved. } \\
\text { Various PV modules } \\
\text { and small energy } \\
\text { storage techniques } \\
\text { were used. Maximum } \\
\text { power conversion } \\
\text { losses are achieved }\end{array}$ & $\begin{array}{l}\text { Ramp rate control } \\
\text { technique used for } \\
\text { power controlling } \\
\text { the battery is used to } \\
\text { control the ramp rate }\end{array}$ \\
\hline [15] & $\begin{array}{l}\text { Reconfigurable } \\
\text { solar converter } \\
\text { and direct } \\
\text { current (DC) }\end{array}$ & $\begin{array}{l}\text { AC/DC } \\
\text { micro-grid }\end{array}$ & Hardware & $\begin{array}{l}\text { PV-to-Grid/PV-to- } \\
\text { Batteries/Batteries-to- } \\
\text { Grid/PV-Battery-to- } \\
\text { Grid }\end{array}$ & $\begin{array}{l}\text { Improves } \\
\text { performance, and } \\
\text { increases reliability } \\
\text { current harmonics } \\
\text { reduced by } 16 \%\end{array}$ & $\begin{array}{l}\text { The DC load is } \\
\text { connected directly to } \\
\text { the DC link without } \\
\text { connecting to the AC } \\
\text { side using an AC / } \\
\text { DC converter. }\end{array}$ \\
\hline [16] & $\begin{array}{l}\text { Reconfigurable } \\
\text { single input } \\
\text { double output } \\
\text { (SIDO) } \\
\text { inverter }\end{array}$ & Micro-grid & $\begin{array}{l}\text { Hardware/ } \\
\text { MATLAB }\end{array}$ & $\begin{array}{l}\text { DC mode/Grid output } \\
\text { mode/Double Grid } \\
\text { Output mode }\end{array}$ & $\begin{array}{lr}\begin{array}{l}\text { Able to } \\
\text { different }\end{array} & \text { operate } \\
\text { conergy } \\
\text { conversion } & \text { modes. } \\
\text { The demand for mixed } \\
\text { power }\end{array}$ & $\begin{array}{l}11 \text { static switches are } \\
\text { added to the single } \\
\text { input dual buck- } \\
\text { boost converter. }\end{array}$ \\
\hline [17] & - & Micro-grid & $\begin{array}{l}\text { Hardware/ } \\
\text { MATLAB }\end{array}$ & $\begin{array}{l}\text { Grid /Islanded } \\
\text { Connect }\end{array}$ & $\begin{array}{l}\text { Suppose a grid failure } \\
\text { makes it easier to } \\
\text { provide uninterrupted } \\
\text { power supply for } \\
\text { critical loads. Solar PV } \\
\text { system performance is } \\
\text { improved }\end{array}$ & $\begin{array}{l}\text { Single-phase quasi - } \\
\mathrm{Z} \text { source (QZS) } \\
\text { inverter has been } \\
\text { used as solar PV } \\
\text { converter. } \\
\text { controller based on } \\
\text { indirect current } \\
\text { control is activated. }\end{array}$ \\
\hline [18] & $\begin{array}{l}\text { Reconfigurable } \\
\text { quasi-Z source } \\
\text { Inverter }\end{array}$ & -- & Hardware & --- & $\begin{array}{l}\text { Ability for a wide } \\
\text { range of voltage } \\
\text { regulation for MPPT. } \\
\text { Partial shading and } \\
\text { impedance mismatch } \\
\text { have reduced energy } \\
\text { loss }\end{array}$ & $\begin{array}{l}\text { Magnetically } \\
\text { integrated QZS } \\
\text { network and } \\
\text { resonant voltage- } \\
\text { double rectifier } \\
\text { (VDR) and its } \\
\text { controller are used }\end{array}$ \\
\hline
\end{tabular}




\section{AUXILIARY UNIT}

Auxiliary unit is used for power generation under emergency condition when all the generation unit and battery storage unit fail to generate the power supply. It is a backup power when the other generation fails to supply the grid. It may be the power of PV, battery and wind and other fuel cell system is unable or insufficient to supply the required load and auxiliary unit is used to charge the battery storage unit (BSU) when PV module is not sufficient to charge the battery. In this section mainly discuss the wind power system, diesel generator system and fuel cell used as alternate source of energy connected to micro grid.

\subsection{Wind power system}

Wind power provides the major share of renewable energy generation in all over the world. The Wind exposed the huge potential of the various regions in matter of wind energy where mountain chains on the coasts create a natural corridor that enhances the stability of winds. The Most of the areas of coasts have the benefit of being next to where electricity is most demanded. The wind generator considered here is a gearless direct driven permanent magnet synchronous generator (PMSG). Basically, three types of wind power generation system available, they are classified as follows: (i) fixed speed induction generators (FSIG), (ii) permanent magnet synchronous generator, and (iii) doubly fed induction generator (DFIG). The maximum power point tracking (MPPT) control mode uses PMSG and DFIG depending on the wind conditions, so the production of a single FSIG cannot be controlled [19]. The summary of some review papers of wind power generation system is presented in Table 2 from the referred paper [20]-[23].

Table 2. Summary of some review papers of wind power generation system

\begin{tabular}{|c|c|c|c|c|}
\hline Author & Technique & Implementation & Advantages & Contribution \\
\hline$[20]$ & $\begin{array}{c}\text { DFIG/ P I/ } \\
\text { SMC/AFLC }\end{array}$ & Hardware & $\begin{array}{l}\text { Use of robust } \\
\text { decoupled DFIG gives } \\
\text { better performance. }\end{array}$ & $\begin{array}{l}\text { Designed the electrical power conversion system based } \\
\text { on DFIG/ Proportional Integration (PI)/Sliding mode } \\
\text { controller (SMC)/ Adaptive fuzzy logic controller } \\
\text { (ALFC) connected to the grid using stator and fed. }\end{array}$ \\
\hline [21] & $\begin{array}{l}\text { NSVM/ } \\
\text { FSVM/ } \\
\text { NSOSMC }\end{array}$ & MATLAB & $\begin{array}{l}\text { Low ripple factor Low } \\
\text { stator current } \\
\text { harmonic distortion }\end{array}$ & $\begin{array}{l}\text { Presented study is on fuzzy space vector modulation } \\
\text { (FSVM) and neural space vector modulation (NSVM) } \\
\text { inverter based on neuron second order sliding mode } \\
\text { control (NSOSMC) strategy in wind system. }\end{array}$ \\
\hline [22] & $\begin{array}{l}\text { PMSG/ } \\
\text { SCIG/ } \\
\text { DFIG/ } \\
\text { SRG }\end{array}$ & -- & $\begin{array}{l}\text { This study showed that } \\
\text { a permanent magnet } \\
\text { synchronous generator } \\
\text { is most suitable for } \\
\text { wind power systems. }\end{array}$ & $\begin{array}{l}\text { Presented comparative analysis of various generators of } \\
\text { wind turbine PMSG/squirrel cage induction generator } \\
\text { (SCIG)/ DFIG/ Switched Reluctance Generator (SRG) } \\
\text { and discussed the various component required for wind } \\
\text { energy system. }\end{array}$ \\
\hline$[23]$ & $\begin{array}{l}\text { MPPT } \\
\text { WT }\end{array}$ & Hardware & $\begin{array}{l}\text { Cost effective system } \\
\text { as per load demand } \\
\text { power supply is } \\
\text { reliable }\end{array}$ & $\begin{array}{l}\text { Proposed the algorithm to calculate the number of } \\
\text { generating unit of MPPT wind turbine (MPPT WT) and } \\
\text { PV for hybrid micro grid. }\end{array}$ \\
\hline
\end{tabular}

\subsection{DG set}

Diesel generator (DG) acts as the main energy source in micro grid power systems. The entire energy storage in the micro grid can be operated in $V / f$ mode, but only a single $V / f$ source is allowed when the micro grid is in separate operation. Therefore, in order to make better use of the energy storage system of the diesel generator, two control methods $V / f$ and $P / Q$ are used as the mode of operation of the diesel generator [24]. The fuel consumption of the diesel generator is described as a straight line with a $\mathrm{y}$-intercept and can be calculated from the (1).

$$
C_{D G}=p_{0} P_{D G}+q_{0} P N_{D G}
$$

Where, $P_{D G}$ is the nominal capacity in $\mathrm{kW}$ and $P N_{D G}$ the electrical output of the diesel generator in $\mathrm{kW}$. The coefficients $p_{0}$ and $q_{0}$ are the intercept of the fuel curve which is the unleaded fuel consumption of the generator divided by its nominal capacity and the slope of the fuel curve representing the marginal fuel consumption the generator. Table 3 presents the summary of integration of diesel system with various renewable energy system is referred from [25]-[31].

\subsection{Energy storage system for micro-grid-super capacitor}

Super-capacitor is a double layer capacitor. The energy is stored by charge transfer at the boundary between electrode and electrolyte. The amount of stored energy is function of the available electrode and electrolyte surface, the size of the ions, and the level of the electrolyte decomposition voltage. Supercapacitors are constituted of two electrodes, a separator and an electrolyte. The two electrodes, made of 
activated carbon provide a high surface area part, defining so energy density of the component. Usually, super-capacitors are divided into two types: double-layer capacitors and electrochemical capacitors. Table 4 presents the summary of published paper of super capacitors [32]-[37].

Table 3. Summary of integration of diesel system with various renewable energy systems

\begin{tabular}{|c|c|c|c|}
\hline Author & Combination & Simulation & Contribution \\
\hline$[25]$ & PV-Wind-Diesel & $\begin{array}{c}\text { Hybrid } \\
\text { optimization } \\
\text { of multiple } \\
\text { energy resources } \\
\text { (HOMER) }\end{array}$ & $\begin{array}{l}\text { Presented the different hybrid system using various renewable energy sources for } \\
\text { village in Saudi Arabia. }\end{array}$ \\
\hline [26] & Wind-Diesel & MATLAB & $\begin{array}{l}\text { Presented the hybrid system of PV, Wind and DG system using genetic algorithm. } \\
\text { In this approach optimization was done for battery storage. }\end{array}$ \\
\hline [27] & PV-Diesel & -- & $\begin{array}{l}\text { The presented the project of PV and DG system and analyze the last } 10 \text {-year } \\
\text { energy generation in Thailand. }\end{array}$ \\
\hline$[28]$ & Wind-PV-Diesel & HOMER & $\begin{array}{l}\text { Wind-PV-diesel hybrid system was designed for village in Saudi Arabia. The main } \\
\text { aim of research is to reduce the diesel consumption and maintain constant supply. }\end{array}$ \\
\hline [29] & PV-Wind-Diesel & HOMER & $\begin{array}{l}\text { Presented the computer-based modeling for hybrid power generation in rural areas } \\
\text { of Iraq and analyzes the cost of power generation of PV and diesel. }\end{array}$ \\
\hline$[30]$ & PV-Diesel & -- & $\begin{array}{l}\text { Presented the work to analyze the performance of } 11 \text { different PV systems. The } \\
\text { result showed that } 10 \mathrm{PV} \text { systems were highly reliable and fulfills the load } \\
\text { demand. }\end{array}$ \\
\hline [31] & Wind-Diesel & -- & $\begin{array}{l}\text { Developed the Wind-Diesel hybrid system for reducing the use of diesel with } \\
\text { integrating high penetration system and compressed air energy storage to } \\
\text { improvement in renewable energy and reduces the cost. }\end{array}$ \\
\hline
\end{tabular}

Table 4. Summary of some review papers of super-capacitor

\begin{tabular}{|c|c|c|c|c|c|}
\hline Author & Technique & Micro-grid & Implementation & Advantages & Contribution \\
\hline$[32]$ & $\begin{array}{l}\text { Wind energy } \\
\text { generation } \\
\text { (WEG)/PV/load } \\
\text { sharing } \\
\text { Proportional - } \\
\text { integral - derivative } \\
\text { (PID) controller }\end{array}$ & Yes & MATLAB & $\begin{array}{l}\text { Using super capacitor in } \\
\text { micro-grid solve the } \\
\text { issue of slow dynamic } \\
\text { of diesel generator } \\
\text { during the startup }\end{array}$ & $\begin{array}{l}\text { Designed energy } \\
\text { management scheme for } \\
\text { standalone DC micro-grid. } \\
\text { Improvement in power } \\
\text { signal quality. }\end{array}$ \\
\hline [33] & $\begin{array}{l}\text { Buck-boost DC-DC } \\
\text { converter }\end{array}$ & No & 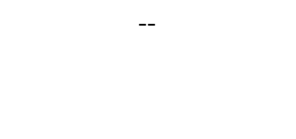 & $\begin{array}{l}\text { Performance of } \\
\text { proposed system was } \\
\text { improving the life of } \\
\text { battery. }\end{array}$ & $\begin{array}{l}\text { Presented the hybrid } \\
\text { approach for energy storage } \\
\text { using Lithium and Super- } \\
\text { Capacitor. }\end{array}$ \\
\hline$[34]$ & $\begin{array}{l}\text { Voltage source } \\
\text { converter }\end{array}$ & Yes & $\begin{array}{l}\text { Power system computer } \\
\text { aided design (PSCAD) }\end{array}$ & $\begin{array}{l}\text { It improves the } \\
\text { performance of bus } \\
\text { voltage and reduces the } \\
\text { usage of battery. }\end{array}$ & $\begin{array}{l}\text { Proposed the energy } \\
\text { management scheme for } \\
\text { batteries and super capacitor } \\
\text { for standalone micro-grid. }\end{array}$ \\
\hline$[35]$ & -- & Yes & MATLAB & $\begin{array}{l}\text { Fast response } \\
\text { High energy density }\end{array}$ & $\begin{array}{l}\text { Presented model reduces the } \\
\text { fluctuation of output load in } \\
\text { micro-grid. }\end{array}$ \\
\hline$[36]$ & $\begin{array}{l}\text { Photo electric } \\
\text { conversion (PEC), } \\
\text { MPPT, P and O } \\
\text { algorithm }\end{array}$ & Yes & MATLAB & $\begin{array}{l}\text { Ability for a wide range } \\
\text { of voltage regulation for } \\
\text { MPPT } \\
\text { Partial shading and } \\
\text { impedance mismatch } \\
\text { have reduced energy } \\
\text { loss }\end{array}$ & $\begin{array}{l}\text { Proposed energy } \\
\text { management scheme for } \\
\text { micro-grid in autonomous } \\
\text { and non-autonomous mode } \\
\text { based on PV array and } \\
\text { storage system. }\end{array}$ \\
\hline [37] & $\begin{array}{l}\text { Electric double layer } \\
\text { capacitor (EDLC) }\end{array}$ & Yes & $\begin{array}{l}\text { PSCAD/Electromagnetic } \\
\text { transient including DC } \\
\text { (EMTDC) }\end{array}$ & $\begin{array}{l}\text { Low Price } \\
\text { High density } \\
\text { Reliability of micro-grid } \\
\text { is improved }\end{array}$ & $\begin{array}{l}\text { To design the energy storage } \\
\text { system based on super } \\
\text { capacitor for the micro-grid } \\
\text { operation. }\end{array}$ \\
\hline
\end{tabular}

\subsection{Solid oxide fuel cell (SOFC)}

$\mathrm{SOFC}$ is a type of fuel cell based on its electrolyte content. It operates at very high temperatures in the range of 500 to $10000 \mathrm{C}$. This type of fuel cell can be used in electrical vehicles or micro-grids as auxiliary energy up to $2 \mathrm{MW}$. Solid oxide fuel cells can be widely used for high efficiency for integrated heating and energy systems. The power conditioning system can be designed by converting DC power into AC power using such a system in the utility grid by generating common solid oxide fuel cell DC energy. Power conditioning systems are used to control energy quality and supply in real and reactive form [38], [39]. Proton exchange 
membrane fuel cell (PEMFC) were utilized in micro-grid [40]. A fuel cell is a type of electrochemical device that generates electricity by converting any chemical energy into electrical energy [41]. The fuel cell can act as a fuel by converting substances like hydrogen and oxygen into electrical energy, while oxygen can be used as an oxidizer. Substances like potassium, sodium hydroxide can be used as electrolytes [42].

\subsection{Hybrid micro-grid system}

A micro-grid consists of a set of various loads, batteries for storage, and a generation system. In a hybrid system, energy can be generated using renewable sources with an energy storage system (batteries) or other storage system is connected to provide stability to micro-grid. For improvement of the micro-grid, continuous solar and wind energy is used. The micro-grid can be operated separately or integrate into a gridbased on the type of energy sources were used [43]-[45]. The most important part of micro-grid is to maintain continuous power supply based on demand but it is very difficult to predict and energy generation may variations depends on availability of renewable energy sources such as solar, and wind. The grid is connected to the grid utility called as grid-tied mode. When micro-grid is disconnected from grid utility then it is in autonomous mode. During the fault diagnosis; micro-grid automatically switched to the autonomous mode. The problem arises in micro-grid is major challenges i.e. voltage dips, harmonic current/voltage and power flicker. Figure 3 depicts a hybrid system for micro-grid. It shows that AC bus is connected to generator, wind turbine and the AC load. AC load can be accessed easily while DC Bus is connected solar cell, battery and fuel cell. converter/inverter can convert ac to dc or dc to ac depends on the requirement of AC/DC load.

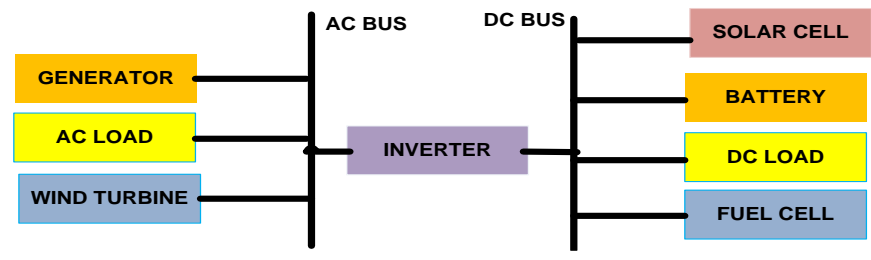

Figure 3. Hybrid system for micro-grid

\section{POWER MANAGEMENT IN HYBRID MICROGRID}

In grid energy storage system, power management is core part to enhance the renewable energy consumption and stable their operation. The power management techniques is presented in [46] for economical beneficial in grid and various optimization objectives, constraints and techniques were designed. Table 5 presents the summary of micro-grid power management [46]-[53]. The most important aspects in hybrid micro-grid are power management strategy is presented in Table 6 [54]-[59]. Energy management approach in micro-grid confirms the output active and reactive power of distributed generation and storage elements and at the same time control voltage and frequency.

Table 5. Summary of micro-grid power management

\begin{tabular}{ccl}
\hline Sr. No. & Authors & Contribution \\
\hline 1 & {$[46]$} & $\begin{array}{l}\text { Author Present the power management strategy to efficiently utilize energy in micro-grid. The relation } \\
\text { between the overall hourly loads fulfilled by local resources and the total hourly load transferred by the main } \\
\text { grid is present in this strategy. It is very obvious that there can be a relatively limited amount of energy fed to } \\
\text { the main grid for loading. } \\
\text { Author presented the overview of energy management system for DC micro-grid. Authors also discussed on } \\
\text { intelligent devices for better utilization of energy, control strategies, and load scheduling techniques. } \\
\text { Author initiated hybrid system for specific energy control based on pumping servitudes and online fuel } \\
\text { utilization optimization. }\end{array}$ \\
3 & {$[47]$} & $\begin{array}{l}\text { Author suggested the hybrid energy storage system for energy management used various batteries and super } \\
\text { capacitors and preventing the fluctuation of DC link bus of the micro-grid. } \\
\text { Author present the novel architecture for power management of multi-micro-grid based on hierarchical bi- } \\
\text { level optimization to resolve renewable energy sources issues. } \\
\text { Author proposed power management algorithm in DC micro-grid based on MPPT to extract the maximum } \\
\text { energy from solar. } \\
\text { Author designed strong mathematical model for energy management in micro-grid based on fuzzy prediction. } \\
\text { These models predict the non-linear behavior and uncertainty in wind energy. } \\
\text { Author present the smart energy management system in AC micro-grid for distributed generation based on } \\
\text { Adaptive neuron fuzzy interference techniques. The Solar and wind energy were used as source of distributed } \\
\text { generation. }\end{array}$ \\
\hline
\end{tabular}


Table 6. Critical summary for energy management system in hybrid micro-grid

\begin{tabular}{|c|c|c|c|c|}
\hline Sr. No & Author & Techniques & Work done & Limitations \\
\hline 1. & [54] & $\begin{array}{l}\text { Linear/Mixed Integer } \\
\text { Linear Programming }\end{array}$ & $\begin{array}{l}\text { Sustainable running, Power sharing based } \\
\text { ON/OFF mixed mode strategies for power } \\
\text { management of micro-grid is proposed. }\end{array}$ & $\begin{array}{l}\text { Due to the high depth of discharge of } \\
\text { the battery, it can deteriorate rapidly. }\end{array}$ \\
\hline 2 & [55] & $\begin{array}{l}\text { Mixed Integer } \\
\text { Linear } \\
\text { Programming }\end{array}$ & $\begin{array}{l}\text { Optimization of fuel cost effective model } \\
\text { based on piecewise linear function of fuel } \\
\text { generator and battery operated has been } \\
\text { proposed. }\end{array}$ & $\begin{array}{l}\text { Uncertainty between PV power and } \\
\text { load demand was not considered. }\end{array}$ \\
\hline 3 & [56] & $\begin{array}{l}\text { Non-linear Power } \\
\text { Flow Control, } \\
\text { Hamiltonian Surface } \\
\text { Shaping and Power } \\
\text { Flow Control }\end{array}$ & $\begin{array}{l}\text { To design a HSSPFC control section was } \\
\text { integrate with the energy storage unit for } \\
\text { providing the stability to AC/DC micro-grid. }\end{array}$ & $\begin{array}{l}\text { The integration with the battery is } \\
\text { disappointing. However, no } \\
\text { alternative solution to Renewable } \\
\text { energy resource mediation is proposed }\end{array}$ \\
\hline 4 & [57] & $\begin{array}{l}\text { multi-objective } \\
\text { optimization } \\
\text { Technique }\end{array}$ & $\begin{array}{l}\text { Proposed the multi-objective optimization } \\
\text { model for energy management for plug in } \\
\text { electric vehicle battery, and prevent the } \\
\text { battery from overcharging and over } \\
\text { discharging. }\end{array}$ & $\begin{array}{l}\text { The effects on the plug and play } \\
\text { characteristics of an electric vehicle } \\
\text { on micro-grid stability have not been } \\
\text { discussed. }\end{array}$ \\
\hline 5 & [58] & $\begin{array}{l}\text { Dynamic } \\
\text { Programming } \\
\text { Approach }\end{array}$ & $\begin{array}{l}\text { The functional value of a conventional } \\
\text { generator and the cost of load shedding are } \\
\text { considered as objective tasks. To reduce the } \\
\text { counting time, the Pont Ragin Maximum } \\
\text { principle has been used. }\end{array}$ & $\begin{array}{l}\text { A high depth of discharge rate is set } \\
\text { which can lead to rapidly discharging } \\
\text { of the battery. The response to the } \\
\text { energy demand was not considered }\end{array}$ \\
\hline 6 & [59] & $\begin{array}{l}\text { Approximate } \\
\text { Dynamic } \\
\text { Programming }\end{array}$ & $\begin{array}{l}\text { The approximate value of the cost-function in } \\
\text { economic transmission and unit charge } \\
\text { operations is considered to be the minimum of } \\
\text { the micro-grid daily energy schedule. }\end{array}$ & $\begin{array}{l}\text { DOD of battery for MG optimized } \\
\text { operation with battery ageing status is } \\
\text { not discussed. }\end{array}$ \\
\hline
\end{tabular}

\section{CONCLUSION}

The study of hybrid renewable energy sources connected to grid and its important component like liion battery, PV cell, wind power, fuel cell and super capacitor have been discussed. The importance of an AU has also been suggested to maintain the continuity of power supply. A critical review paper has been prepared based on the comparison to the conventional system. The energy management system of different renewable energy sources connected to grid is discussed which gives information to the researchers to do more research work. Thus, the paper suggests the performance of different component study and to build a hybrid renewable energy generation considering best performance wise component which provides energy as per the load requirement of the grid in a continuous manner throughout the year. Comparison of parameters and its performance analysis in respect to conventional system has also been discussed. The importance of Li ion battery has been suggested in our proposed system due to the significant property of high energy density and long-life cycle. The need for a different defense plan from the current one has been clarified based on different approaches. The authors have taken an attempt to present the paper based on the component study and critical energy management strategies to cater the load demand in a continuous, effective, economic and reliable way under adverse load condition.

\section{REFERENCES}

[1] N. Nitta, F. Wu, J. T. Lee, and G. Yushin, "Li-ion battery materials: present and future," Materials Today, vol. 18, no. 5, pp. 252-264, 2015, doi: 10.1016/j.mattod.2014.10.040.

[2] C. Mao, R. E. Ruther, J. Li, Z. Du, and I. Belharouak, "Identifying the limiting electrode in lithium-ion batteries for extreme fast charging," Electrochemistry Communications, vol. 97, pp. 37-41, 2018, doi: 10.1016/j.elecom.2018.10.007.

[3] Y. Lu, L. Yu, and X. W. 4(David) Lou, "Nanostructured Conversion-type Anode Materials for Advanced Lithium-Ion Batteries," Chem, vol. 4, no. 5, pp. 972-996, 2018, doi: 10.1016/j.chempr.2018.01.003.

[4] A. Mishra et al., "Electrode materials for lithium-ion batteries," Materials Science for Energy Technologies, vol. 1, no. 2, pp. 182-187, 2018, doi: 10.1016/j.mset.2018.08.001.

[5] L. Masias, J. Marcicki, and W. A. Paxton, "Opportunities and Challenges of Lithium-Ion Batteries in Automotive Applications," ACS Energy Letters, vol. 6, no. 2, pp. 621-630, 2021, doi: 10.1021/acsenergylett.0c02584.

[6] D. Da. "Li-ion batteries: basics, progress, and challenges," Energy Science \& Engineering, vol. 3, no. 5, pp. 385-418, 2015, doi: 10.1002/ese3.95.

[7] C Iclodean, B. Varga, N. Burnete, D. Cimerdean, and B. Jurchis, "Comparison of different types of Electric Vehicle," IOP Conference Series Materials Science Engineering, vol. 252, no. 1, pp. 1-11, 2017, doi: 10.1088/1757-899X/252/1/012058.

[8] T. O. Ely, D. Kamzabek, and D. Chakraborty, "Batteries Safety: Recent Progress and Current Challenges," Frontiers in Energy Ressearch, pp. 1-46, 2019, doi: 10.3389/fenrg.2019.00071.

[9] T. Chen et al., "Applications of Lithium-Ion Batteries in Grid-Scale Energy Storage Systems," Transactions of Tianjin University, pp. 208-217, 2020, doi: 10.1007/s12209-020-00236-w. 
[10] H. C. Hesse, M. Schimpe, D. Kucevic, and Jossen, "Lithium-ion battery storage for the grid: a review of stationary battery storage system design tailored for applications in modern power grids," Energies, vol. 10, no. 12, pp. 1-42, 2017, doi: 10.3390/en10122107.

[11] S. Das and A. K. Akella, "A Control Strategy for Power Management of an Isolated Micro Hydro-PV-Battery Hybrid Energy System," 4th International Conference on Electrical Energy Systems (ICEES), 2018, pp. 397-401, doi: 10.1109/ICEES.2018.8442350.

[12] Y. Jia, T. Liu, Y. Tai, H. Wu, and Y. Xing, "A Si C-Based Dual-Input Buck-Boost Converter with Independent MPPT For Photovoltaic Power Systems," IECON 2018 - 44th Annual Conference of the IEEE Industrial Electronics Society, 2018, pp. 16401645, doi: 10.1109/IECON.2018.8592687

[13] H. Kim, B. Parkhideh, T. D. Bongers, and H. Gao, "Reconfigurable Solar Converter: A Single-Stage Power Conversion PV-Battery System," IEEE Transactions on Power Electronics, vol. 28, no. 8, pp. 3788-3797, 2013, doi: 10.1109/TPEL.2012.2229393.

[14] K. A. H. Lakshika et al., "Reconfigurable solar photovoltaic systems: A review," Introducing Heliyon Chemical Engineering, vol. 6, no. 11, 2020, doi: 10.1016/j.heliyon.2020.e05530.

[15] N. Sasidharan and J. G. Singh, "A Novel Single-Stage Single-Phase Reconfigurable Inverter Topology for a Solar Powered Hybrid AC/DC Home," IEEE Transactions on Industrial Electronics, vol. 64, no. 4, pp. 2820-2828, 2017, doi: 10.1109/TIE.2016.2643602.

[16] R. Rizzo, I. Spina, and P. Tricoli, "A single input dual buck-boost output reconfigurable converter for distributed generation," International Conference on Clean Electrical Power (ICCEP), 2015, pp. 767-774, doi: 10.1109/ICCEP.2015.7177579.

[17] M. Chen, S. Lin, J. Cai, and D. Chou, "Implementing a single-phase quasi-Z-source inverter with the indirect current control algorithm for a reconfigurable PV system," IEEE International Conference on Industrial Technology (ICIT), 2016, pp. 323-328, doi: 10.1109/ICIT.2016.7474772.

[18] A. Chub, D. Vinnikov, R. Kosenko, and E. Liivik, "Wide Input Voltage Range Photovoltaic micro converter With Reconfigurable Buck-Boost Switching Stage," IEEE Transactions on Industrial Electronics, vol. 64, no. 7, pp. 5974-5983, July 2017, doi: 10.1109/TIE.2016.2645891.

[19] S. Marmouh, M. Boutoubat, and L. Mokrani, "MPPT fuzzy logic controller of a wind energy conversion system based on a PMSG," 8th International Conference on Modelling, Identification and Control (ICMIC), 2016, pp. 296-302, doi: 10.1109/ICMIC.2016.7804126.

[20] M. Benkahla, R. Taleb, and Z. Boudjema, "Comparative Study of Robust Control Strategies for a DFIG-Based Wind Turbine," International Journal of Advanced Computer Science and Applications (IJACSA), vol. 7, no. 2, pp. 455-462, 2016, doi: 10.14569/IJACSA.2016.070261.

[21] H. Benbouhenni, "Comparative Study Between NSVM and FSVM Strategy for a DFIG-based Wind Turbine System Controlled by Neuro-Second Order Sliding Mode," Majlesi Journal of Mechatronic Systems, vol. 7, no. 1, pp. 33-43, 2018.

[22] C. H. Chong, A. R. H. Right, and I. Ali, "Wind turbine modelling and simulation using MATLAB / SIMULINK," IOP Conference Series: Materials Science and Engineering, pp. 1-10, 2021, doi: 10.1088/1757-899X/1101/1/012034.

[23] F. Canziani, R. Vargas, and J. A. G. Roque, "Hybrid Photovoltaic-Wind micro-grid with Battery Storage for Rural Electrification: A Case Study in Perú," Frontiers in Energy Research, 2021 doi: 10.3389/fenrg.2020.528571.

[24] Y. Fu, J. Tang, J. Cui, J. Yang, and S. Cheng, "Research on capacity configuration optimization for island micro-grid with PVwind-diesel-battery and seawater desalination load," IOP Conference Series: Earth and Environmental Science, 2020, doi: 10.1088/1755-1315/615/1/012078

[25] S. Rehman and I. El-Amin, "Study of a solar pv/wind/diesel hybrid power system for a remotely located population near Arar, Saudi Arabia," Energy Exploration \& Exploitation, 2015, vol. 33, no. 4, pp. 591-620, https://doi.org/10.1260\%2F01445987.33.4.591

[26] G. Merei, C. Berger, and D. U. Sauer, "Optimization of an off-grid hybrid PV-Wind-Diesel system with different battery technologies using genetic algorithm," Solar Energy, vol. 97, pp. 460-473, 2013, https://doi.org/10.1016/j.solener.2013.08.016.

[27] W. Krueasuk, P. Bhasaputra, W. Pattaraprakorn, and S. Nirukkanaporn, "Renewable Energy for Rural Electrification in Thailand: A Case Study of Solar PV Rooftop Project," GMSARN International Journal, vol. 9, no.2, pp. 51-58, 2015.

[28] S. Rehman, M. M. Alam, J. Meyer, and L. M. Al- Hadhrami, "Feasibility study of a Wind-PV-Diesel hybrid power system for a village," Renewable Energy, vol. 38, no. 1, pp. 258-268, 2012, doi: 10.1016/j.renene.2011.06.028.

[29] Q. Hassan, M. Jaszczur, and J. Abdulateef, "Optimization of PV/wind/diesel hybrid power system in homer for rural electrification,” Journal of Physics: Conference Series, 2016, vol. 745, no. 3, pp. 1-9, 2016.

[30] A. M. Mahmud and R. E. Blanchard, "Assessing a rural electrification program in Malaysia: System performance analysis on 11 solar PV-diesel hybrid systems," 4th International Conference on the Development in the in Renewable Energy Technology (ICDRET), 2016, pp. 1-5, doi: 10.1109/ICDRET.2016.7421506.

[31] N. Martinez et al., "Computer Model for a Wind-Diesel Hybrid System with Compressed Air Energy Storage," Energies, 2019, vol. 12, no. 18, pp. 1-18, 2019, doi: 10.3390/en12183542.

[32] A. Yasin, "Energy Management of a Stand-Alone DC micro-grid Based on PV/Wind/Battery/ Diesel Gen. Combined with SuperCapacitor," International Journal of Renewable Energy Research, vol. 9, no.4, pp. 1812-1826, 2019

[33] V. G. Chirkin, L. Y. Lezhnev, D. A. Petrichenko, and I. A. Papkin, “A Battery-Super capacitor Hybrid Energy Storage System Design and Power Management," International Journal of Pure and Applied Mathematics, vol. 119, no. 15, pp. 2621-2625, 2018.

[34] Y. Ren, S. J. Rind, and L. Jiang, "A coordinated control strategy for battery/super capacitor hybrid energy storage system to eliminate unbalanced voltage in a standalone AC micro-grid," Journal of Intelligent Manufacturing and Special Equipment, vol. 1 , no. 1, pp. 3-32, 2020.

[35] P. Wongdet and B. Marungsri, "Study of Hybrid Energy Storage System for High-Rate Power Mitigation in micro-grid," Advances in Engineering Research, in 2nd International Conference on Electrical Engineering and Automation, ICEEA 2018.

[36] R. J. Kumar and S. Nivedha, "Analysis of Energy Management in Micro-Grid with Distributed Generation and Hybrid Energy Storage System," International Research Journal of Engineering and Technology, vol. 7, no. 12, pp. 1040-1046, 2020.

[37] N. Gustavo, J. Torres, M. Blanco, J. Najera, M. S. Herran, and M. Lafoz, "Present and Future of Super capacitor Technology Applied to Powertrains, Renewable Generation and Grid Connection Applications," Energies, vol. 14, no. 11, pp. 1-29, 2021, doi: 10.3390/en14113060.

[38] K. Ahmed, O. Farrok, Md. M. Rahman, Md. S. Ali, Md. M. Haque, and A. K. Azad, "Proton Exchange Membrane Hydrogen Fuel Cell as the Grid Connected Power Generator," Energies, vol. 13, no. 24, pp. 1-20, 2020, doi: 0.3390/en13246679.

[39] F. M. Guangul and G. T. Chala, "A comparative study between the seven types of fuel cells," Applied Science and Engineering Progress, vol. 13, no. 3, pp. 185-194, 2020, doi: 10.14416/j.asep.2020.04.007. 
[40] M. Ma'arof, G. T. Chala, and S. Ravichanthiran, "A study on microbial fuel cell (MFC) with graphite electrode to power underwater monitoring devices," International Journal of Mechanical and Technology, vol. 9, pp. 98-105, 2018.

[41] Y. E. G. Vera, D. R. López, and B. J. L. Agustín, "Energy Management in micro-grids with Renewable Energy Sources: A Literature Review," Applied Sciences, vol. 9, no. 18, pp. 1-28, doi: 10.3390/app9183854.

[42] A. Guichi, A. Talha, E. M. Berkouk, and S. Mekhilef, "Energy management and performance evaluation of grid connected PVbattery hybrid system with inherent control scheme," Sustainable cities and society, vol. 41, pp. 490-504, doi: 10.1016/j.scs.2018.05.026.

[43] C. Natesan, S. Ajithan, S. Chozhavendhan, and A. Devendiran, "Power management strategies in micro-grid: A survey," International Journal of Renewable Energy Research (IJRER), 2015, vol. 5, no. 2, pp. 334-40.

[44] S. K. Bhuyan, P. K. Hota, and B. Panda, "Power Quality Analysis of a Grid-Connected Solar/Wind/Hydrogen Energy Hybrid Generation System," International Journal of Power Electronics and Drive System (IJPEDS), vol. 9, no. 1, pp. 377-389, 2018, doi: 10.11591/ijpeds.v9n1.pp377-389.

[45] H. M. Sultan, A. A. Z. Diab, K. N. Oleg, and Z. S. Irina, "Design and evaluation of PV-wind hybrid system with hydroelectric pumped storage on the National Power System of Egypt," Global Energy Interconnection, vol. 1, no. 3, 2018, doi: 10.14171/j.2096-5117.gei.2018.03.001.

[46] H. Ahmad, A. Ahmad, and S. Ahmad, "Efficient Energy Management in a micro-grid," International Conference on Power Generation Systems and Renewable Energy Technologies (PGSRET), 2018, pp. 1-5, doi: 10.1109/PGSRET.2018.8685946.

[47] T. Shah and Z. A. Ansari, "An Overview of Intelligent Energy Management System for DC micro-grid: System and Communication Architecture and Application in Power Distribution System," IEEE 13th International Conference on Industrial and Information Systems (ICIIS), 2018, pp. 1-4, doi: 10.1109/ICIINFS.2018.8721384.

[48] O. Djelailia, S. Necaibia, M. S. Kelaiaia, F. Merad, H. Labar, and H. Chouial, "Optimal Fuel Consumption Planning and Energy Management Strategy for a Hybrid Energy System with Pumped Storage," 1st International Conference on Sustainable Renewable Energy Systems and Applications (ICSRESA), 2019, pp. 1-6, doi: 10.1109/ICSRESA49121.2019.9182506.

[49] K. Sayed, A. M. Kassem, I. Aboelhassan, A. M. Aly, and A. G. Abo-Khalil, "Energy Management and Control Strategy of DC Microgrid Including Multiple Energy Storage Systems," 21st International Middle East Power Systems Conference (MEPCON), 2019, pp. 736-741, doi: 10.1109/MEPCON47431.2019.9008076.

[50] Zhao et al., "Energy Management of Multiple micro-grids Based on a System of Systems Architecture," IEEE Transactions on Power Systems, vol. 33, no. 6, pp. 6410-6421, 2018, doi: 10.1109/TPWRS.2018.2840055.

[51] D. M. R. Korada, M. K. Mishra, and R. S. Yallamilli, "Dynamic Energy Management in DC micro-grid using Composite Energy Storage System," IEEE International Conference on Power Electronics, Smart Grid and Renewable Energy (PESGRE2020), 2020, pp. 1-6, doi: 10.1109/PESGRE45664.2020.9070693.

[52] F. Valencia, J. Collado, D. Sáez, and L. G. Marín, "Robust Energy Management System for a Micro-grid Based on a Fuzzy Prediction Interval Model," IEEE Transactions on Smart Grid, vol. 7, no. 3, pp. 1486-1494, 2016, doi: 10.1109/TSG.2015.2463079.

[53] U. B. Tayab, F. Yang, M. El-Hendawi, and J. Lu, "Energy Management System for a Grid-Connected Micro-grid with Photovoltaic and Battery Energy Storage System," Australian \& New Zealand Control Conference (ANZCC), 2018, pp. 141-144, doi: 10.1109/ANZCC.2018.8606557.

[54] J. B. Almada, R. Leao, R. Sampaio, and G. Barroso, "A centralized and heuristic approach for energy management of an ac microgrid," Renewable and Sustainable Energy Reviews, vol. 60, pp. 1396-1404, 2016, doi: 10.1016/j.rser.2016.03.002.

[55] S. M. Ashabani and Y. A. I. Mohamed, "General Interface for Power Management of Micro-Grids Using Nonlinear Cooperative Droop Control,” IEEE Transactions on Power Systems, vol. 28, no. 3, pp. 2929-2941, 2013, doi: 10.1109/TPWRS.2013.2254729.

[56] N. Anglani, G. Oriti, and M. Colombini, "Optimized Energy Management System to Reduce Fuel Consumption in Remote Military Microgrids," IEEE Transactions on Industry Applications, vol. 53, no. 6, pp. 5777-5785, 2017, doi: 10.1109/TIA.2017.2734045.

[57] F. Jiao, Y. Zou, X. Zhang, and R. Zou, "Multi-objective optimal energy management of micro-grids including plug-in electric vehicles with the vehicle to grid capability for energy resources scheduling," Proceedings of the Institution of Mechanical Engineers, Part A: Journal of Power and Energy, vol. 235, no. 3, pp. 563-580, 2020, doi: 10.1177/0957650920942998.

[58] B. Heymann, J. F. Bonnans, P. Martinon, F. J. Silva, F. Lanas, and G. J. Est'evez, "Continuous optimal control approaches to microgrid energy management," Energy Systems, vol. 9, pp. 59-77, 2018

[59] M. Střelec and J. Berka, "Micro-grid energy management based on approximate dynamic programming," IEEE PES ISGT Europe, 2013, pp. 1-5, doi: 10.1109/ISGTEurope.2013.6695439.

\section{BIOGRAPHIES OF AUTHORS}

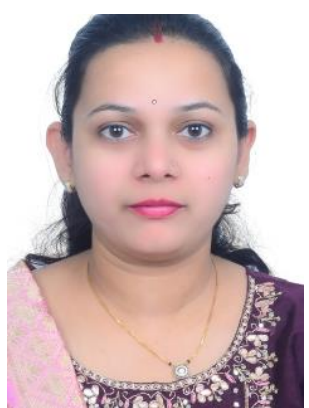

Pranita Rathod (iD SI SC P has graduated \& post graduated in Electrical and power Engineering from Govrment College of Engineering, Amravati, India in 2012 and 2017 respectively. Her research interest includes renewable generation systems, microgrid, power system analysis. She can be contacted at email: pranita.rathod@ghru.edu.in 


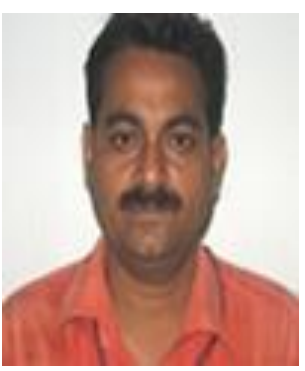

Sanjoy Kumar Mishra (D) 8d SC P has received the Ph.D in Electrical Engineering from KIIT University, Bhubaneswar, India. Master in Engineering and Bachelor in 2003 \& 1995 respectively. Currently, he is working as Associate Professor in Electrical Engineering from G H Raisoni University, Amravati, India. His area of interest includes soft computing tools applying in power system stability, signal processing algorithm in power system protection and hybrid energy and microgrid. He is also the reviewer of Elseviere, IEEE Acess and IEEE system Journal. He can be contacted at email: sanjay29y@gmail.com

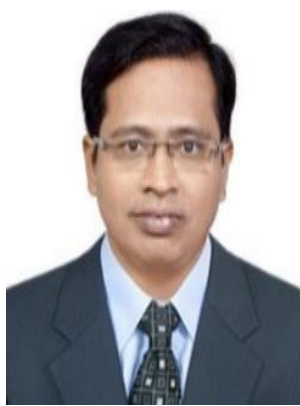

Sujit Kumar Bhuyan (D) SC P Sas graduated \& post graduated in Electrical Engineering in 2007 \& 2012 respectively and completed his Ph.D in 2019 from KIIT University, Bhubaneswar, India. Currently, he is working as a head of Resource Assessment and Asset Analysis (RAAA) in Manikaran Analytics Limited, Delhi, India. His research interests include Renewable Energy Generation Systems, Power Electronics Converters and Inverters. He can be contacted at email: sujit.kumar84@gmail.com 